\title{
The Art of Biology Teaching
}

\author{
Yan Li \\ Biology Department \\ Dezhou University \\ Dezhou 253023, China \\ Tel: 86-534-898-2127Ｅ-mail: lylxy0524@126.com
}

\begin{abstract}
With biology being a rapidly developed branch of natural science closely related to human beings, a systematic application of a variety of teaching arts in its teaching course seems particularly significant in students' mastery of this subject. Therefore, this article aims at putting forward some techniques in applying some important teaching arts as well as teachers' basic qualities.
\end{abstract}

Keywords: Biology, Teaching, Art

Art includes teaching as well as music, dancing, drama and painting. Actually, the art of teaching is a harmonious unity between the reproduction of science and artistic manifestation, a comprehensive artistic creative activity in which both teachers and students are to be developed (Yang, 1997). With biology an experiment-based branch of natural science studying the classification, structure, function, behavior and evolution of different levels in creatures, it seems particularly important to employ a variety of teaching arts to put across different life phenomena and their basic laws in its teaching.

\section{Arousing students' interest}

Here "interest" refers to a tendency to explore things actively. Teachers' methods and techniques of teaching play an important role in students' interest in studying certain subject. First of all, students should be helped to get a general understanding of the subject of biology. Although they began to learn this biology in high school, those basic knowledge didn't give them a whole picture or the fundamental knowledge about the basic frame of biological theory system. If they are still lacking in such knowledge during their college study, they will feel it quite hard to understand those areas related to biology. Meanwhile, students' interest in biology learning will be stimulated with a general mastery of its objects, methods and theory system. Second, more practical projects should be provided to emphasize interdisciplinary practice. These projects, mentioning the core of biology though they display the development in different aspects, will arouse keen enthusiasm for biology among students. Third, basic knowledge should be integrated with latest development. The former is relatively stable while the latter is in constant development. Therefore, the latter should be introduced in a flexible and brief way to explain the extension of basic concepts, the application of basic principles as well as the development of basic technologies. However, due to the limited class hour, relevant content should be explained naturally but not in every detail. Due to their interest in extending their knowledge and exploring the interdisciplinary nature at an academic level, students are more willing to approach as well as learn about biology.

\section{Stimulating students' emotions}

Emotion refers to the experience in attitudes which is said "to dominate anything else". Therefore, it seems more important to arouse people's emotions than thinking. According to Lenin, there wouldn't be people's pursuit for truth without emotions. First of all, every class should be prepared delicately, during which key and difficult points are expected to be thought over several times and different explanation ways should be compared in terms of advantages and disadvantages to choose the one easier to understand and better to arouse students' interest in exploration and discovery, to help them to experience the fun of learning as well as to be creative. Second, teaching methods should be emphasized to stimulate students' learning interest. There is no place for the process of knowledge birth and the methods for knowledge application in students' textbooks, just in which rich humanity gets embodied in the breakthroughs, failures or sufferings of science. It is suggested to select some stories about the history of scientific development related to the teaching content in order to enable students to experience some significant spirits in science, such as seeking the truth from facts, daring to explore new fields and overcoming one after another difficulty, hence 
calling for their responsibilities to promote the development of civilization and benefit mankind.

In addition, teachers can link the teaching content with the achievements of our nation or mother school to arouse students' patriotism, pride and affection. Third, the beauty of biology should be displayed in teaching. According to the remarks of Yang Zhenning, a winner of a Nobel Prize, on "beauty and physics" and "my admiration for the beauty and power of math", it is revealed that there is "beauty in precise laws deeper than that in natural phenomena" and "beauty in profound theory framework". Inspired by the wisdom of Yang Zhenning, students can be guided to experience and appreciate the beauty embodied in the biological field, to realize the value of "Number One Propel" and to achieve their passion for further exploration into science.

Class teaching is a visual and audio art, in which teachers' emotions are called for to encourage students. In most cases, certain artistic effects can be achieved by coordinating class atmosphere, creating teaching situations, exerting emotions when giving lectures. In this way, students will be so absorbed in class that the whole classroom is silent. While at some critical points, students' emotions will be stimulated, even responding to the teacher with laughter or applauses.

\section{Employing a variety of teaching means flexibly}

During the teaching process, all kinds of teaching means should be employed to visualize the teaching content, to improve teaching effects and therefore to encourage students' learning enthusiasm. Currently, with the development of multimedia teaching, CAI courseware is put into extensive practice, with which the structure at the level of organisms, tissues and organs, cells as well as molecules can be displayed in a visualized way. Especially as for molecular structure and its action principle, the abstract and complicated content can be simplified with multimedia tools, making it easier to be understood by students. However, some problems should be improved during the application of multimedia in biology teaching, for example, well-designed charts and animation, instead of a large amount of words, should be relied on. In addition, it will also help to achieve the best teaching effect to systematize what is taught with precise board writing. (Zhu, 2002)

\section{Improving teachers' teaching and control abilities}

Teachers' all-round abilities are expected to be improved in the conversion from scientific teaching to artistic teaching. As for biology teachers, the following abilities are significant: first, their abilities in scientific research should be improved. Teaching quality is the comprehensive reflection of teachers' abilities. Although a teacher's research abilities cannot tell all about his teaching quality, his teaching cannot be satisfactory if he is poor in scientific research. Due to the present rapid development giving birth to new knowledge and findings in biological science, only by improving their scientific research abilities will biology teachers be able to master the subject system, systematize knowledge points and therefore to improve their teaching quality. Second, their verbal abilities should be enhanced. The mastery of some necessary verbal techniques will make the language in teaching more expressive and attractive. Generally speaking, it is expected to be precise, fluent, clear, easy to understand as well as vivid. With the language in teaching as the tool for not only explaining knowledge but also cultivating potentials, wisdom and personality, verbal abilities play a critical role in teaching effects $(\mathrm{Xi}, 2004)$. Third, they should have rich imagination, with which teachers will be able to convert those complicated things into some concrete and easy ones by employing illustration or metaphor. In addition, teachers are supposed to have excellent organization abilities, which are a basic teaching capacity as well as a teaching art due to the nature of teaching activities. Only with a well-designed and carefully-arranged teaching content will teachers achieve the unity among some different factors in the teaching process.

To sum up, teaching is a branch of science as well as art. In order to unite the two, teachers should make it clear why to teach, what to teach and how to teach. Only a teaching process with the above three ideas can be called teaching art. No fixed pattern as it has, teaching art should conform to the laws and characteristics of this subject.

Biology is characterized by its rapid development, interdisciplinary width, multi-level depth, network-based knowledge system, dynamics of the life process and its descriptive teaching method. According to the above, when exploring the teaching art in biology, teachers should explore effective teaching patterns and methods, make reasonable use of teaching means, fully exerting teachers' individual potentials based on their efforts to enrich their knowledge structure and content, hence converting scientific teaching to artistic one.

\section{References}

Xi, Xiuzhang. (2004). A Brief Research on the Relationship Between Teaching Pattern and Teaching Art. Contemporary Teaching Education. 18, 43.

Yang, Qingsong. (1997). On the Nature of Ancient and Modern Teaching Art. Shanghai Research on Education, 6, pp46-47.

Yang, Zhenning. (1998). Yang Zhenning's Anthology, East China Normal University Press.

Zhu, Wenhui. Tan, Tiancheng. Li, Shu. Tian, Li. (2002). On the Characteristics of Teaching Art. Meitan Higher Education, 5, pp123-124. 